\title{
2,4-Dinitrophenol (DNP): A Weight Loss Agent with Significant Acute Toxicity and Risk of Death
}

\author{
Johann Grundlingh • Paul I. Dargan • \\ Marwa El-Zanfaly • David M. Wood
}

Published online: 8 July 2011

(C) American College of Medical Toxicology 2011

\begin{abstract}
Dinitrophenol (DNP) is reported to cause rapid loss of weight, but unfortunately is associated with an unacceptably high rate of significant adverse effects. DNP is sold mostly over the internet under a number of different names as a weight loss/slimming aid. It causes uncoupling of oxidative phosphorylation; the classic symptom complex associated with toxicity of phenol-based products such as DNP is a combination of hyperthermia, tachycardia, diaphoresis and tachypnoea, eventually leading to death. Fatalities related to exposure to DNP have been reported since the turn of the twentieth century. To date, there have been 62 published deaths in the medical literature attributed to DNP. In this review, we will describe the pattern and pathophysiology of DNP toxicity and summarise the previous fatalities associated with exposure to DNP.
\end{abstract}

\section{J. Grundlingh}

Emergency Medicine, Whittington Hospital,

London, UK

\section{P. I. Dargan • D. M. Wood}

Guy's and St Thomas' NHS Foundation Trust

and King's Health Partners,

London, UK

P. I. Dargan · D. M. Wood

King's College London,

London, UK

\section{El-Zanfaly}

Emergency Medicine, Northwick Park Hospital, London, UK

D. M. Wood $(\varangle)$

Medical Toxicology Office,

2nd Floor, Bermondsey Wing,

Guy's Hospital, Great Maze Pond,

London, SE1 9RT, UK

e-mail: david.wood@gstt.nhs.uk
Keywords Dinitrophenol · Weight loss · Toxicity · Fatality

\section{Introduction}

The pharmacologic treatment of obesity has been challenging. Previously, amphetamine derivatives, such as dexflenfluramine, fenfluramine and phentermine, were used as centrally active appetite suppressants; however, their use is associated with valvular heart disease and the development of pulmonary hypertension. Sibutramine (Reductil ${ }^{\mathrm{TM}}$ Abbott Laboratories), a newer centrally active appetite suppressant and the lipase inhibitor orlistat (Xenical ${ }^{\mathrm{TM}}$, Roche) are currently being used as 'diet pills', but have unpleasant side effects. However, for the majority of individuals with morbid obesity (body mass index $>35 \mathrm{~kg} / \mathrm{m}^{2}$ ), obesity surgery ('gastric banding') is often the treatment modality of choice, particularly in those associated severe co-morbidities [1]. Regular use of 2, 4-dinitrophenol (DNP) is reported to cause rapid loss of weight, but unfortunately is associated with an unacceptably high rate of significant side effects [2].

The first death due to DNP $\left(\mathrm{C}_{6} \mathrm{H}_{4} \mathrm{~N}_{2} \mathrm{O}_{5}\right)$ was reported in 1918 and was secondary to occupational exposure [3]. Currently marketing of DNP, which is predominately through the internet, is targeted towards primarily body builders who are attempting to lose fat but retain muscle bulk. Additionally, it is widely available on the internet and is marketed as a 'safe weight loss' drug. Individuals are able to purchase 'large quantities', such as kilograms of DNP powder or hundreds/thousands of DNP-containing tablets. There are many regimes for taking the drug, all of which rely on the metabolic stimulatory effects of the drug $[4,5]$. It has a small therapeutic index and is extremely dangerous in overdose. In this review, we will summarise the pharmacology of DNP, the potential mechanisms for its 
toxicity and the clinical evidence of harm associated with the use of DNP.

\section{Search Strategy}

The National Center for Biotechnology Information (PubMed) system was searched utilising the search terms 'dinitrophenol', 'dinitrophenol overdose' and 'dinitrophenol death' in titles and abstracts. All the relevant abstracts were screened by one author (JG) and those that did not describe death(s) due to DNP were excluded from the pool of results. All the remaining articles were retrieved and scrutinized to ensure they convincingly described death(s) due to DNP. All articles describing deaths due to other compounds similar to DNP (e.g. dinitro-crescol) were excluded. Citations and references of the remaining articles were searched, retrieved and evaluated in the same way as the original search results. Additional online searches for suppliers of DNP were done using an internet search engine (Google) with the terms 'dinitrophenol' and 'dinitrophenol weight loss'.

\section{History of Dinitrophenol}

The French used DNP in the manufacture of munitions during the First World War [6, 7]. Since then, it has also been used as a dye, wood preserver, herbicide and photographic developer. It was Maurice Tainter at Stanford University in 1933 who discovered that the human consumption of DNP led to significant weight loss and soon it was popularised as a weight loss drug [8]. It was included in over-the-counter medications and was sold to the public without requiring a prescription.

Its use for those wishing to lose weight was encouraged by reports of rapid, safe weight loss [7,8]. DNP can cause a significant increase in the basal metabolic rate [7,8]. This leads to weight loss by burning more fat and carbohydrates [9], and weight loss of up to $1.5 \mathrm{~kg}$ per week is reported without significant side effects. However, there seems to be significant variation in individual responses with an average metabolic rate increase of $11 \%$ for every $100 \mathrm{mg}$ of DNP when taken regularly [10-12]. As more side effects, especially cataracts, were reported, DNP was labelled as 'extremely dangerous and not fit for human consumption' by the Federal Food, Drug and Cosmetic Act of 1938 [2, 13].

After 1938, medical prescription of DNP stopped and cases of poisoning due to medical intake were no longer reported, but case reports of deaths associated with the ingestion of DNP still emerged [14, 15]. It is anecdotally reported to have been prescribed to the Russian soldiers during World War II to keep them warm [16].
In 1981, a physician (Dr. Bachynsky) in TX, USA processed industrial DNP into tablets which he marketed/ dispensed under the trade name 'Mitcal' through his private weight loss clinic [16]. He advertised that weight loss occurred using 'Mitcal' through a mechanism he called intracellular hyperthermia therapy. It is alleged in subsequent court proceedings that over 14,000 people were treated by Dr. Bachynsky. Individuals using Mitcal started reporting adverse effects, such as fever, shortness of breath and sweating, to the US Food and Drugs Administration in late 1982. Additionally, there was a fatality associated with an intentional overdose of 'Mitcal' in 1984. Following further investigation, Dr. Bachynsky was convicted in 1986 of drug law violations, fined and prohibited from dispensing DNP to any patients. However, he continued to use DNP for a variety of different 'medicinal claims' and was eventually jailed for fraud in 2008 in the USA in relation to the marketing of a company that was developing DNP being used in Europe as a cancer treatment known as intracellular hyperthermia therapy [17].

The UK Food Standard Agency issued a warning in 2003, labelling DNP as 'not fit for human consumption'. This warning was aimed specifically at bodybuilders, to avoid its use due to significant potential for short-term and long-term harm, following the hospitalisation of a Finish bodybuilder after having taken DNP [18].

Despite this, DNP remains widely available and as discussed below in more detail, can be purchased over the internet, particularly from online pharmacies. Additionally, there are instructions for the synthesis of DNP online for selfmanufacture. As noted above, DNP has been banned as a weight loss drug in the USA, and in the UK, it has been labelled as a hazardous chemical under the Clean Air Act $[2,18]$. Despite this legislation and warnings of harm associated with its use, reports of deaths due to the use of DNP have increased in the last few years (Fig. 1), and the

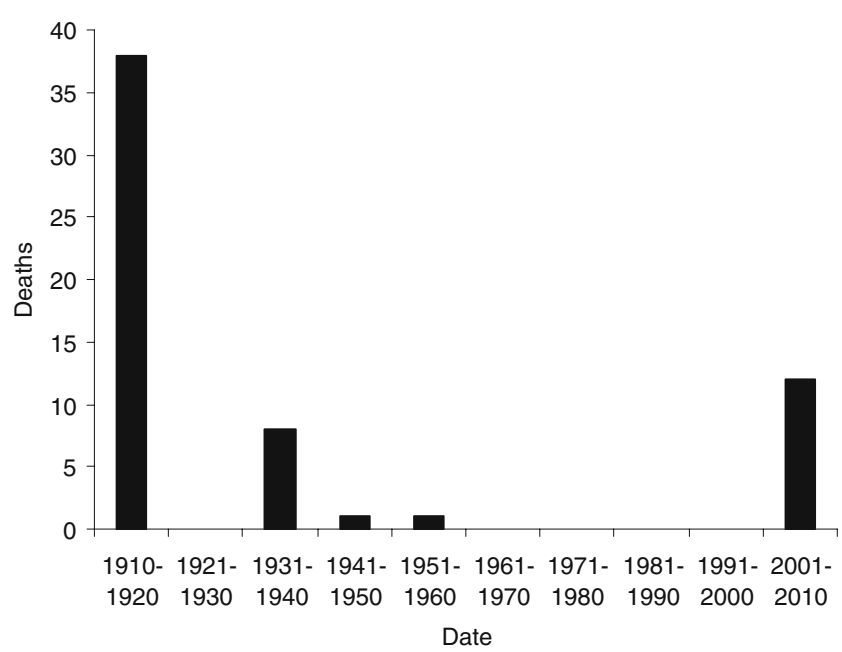

Fig. 1 Graphical presentation of DNP-related deaths by decade 
Table 1 Summary of previously published fatalities relating to exposure to DNP including basic demographics, amount of exposure and maximal temperature recorded pre-death

\begin{tabular}{|c|c|c|c|c|c|c|}
\hline Sex & Age & Type of exposure & Dose & Time to death & Maximum temperature & Year [reference] \\
\hline M & NR & Occupational & N/A-occupational & $14 \mathrm{~h} 30 \mathrm{~min}$ & $40.5^{\circ} \mathrm{C}\left(104.9^{\circ} \mathrm{F}\right)$ & $1916[86]$ \\
\hline M & NR & Occupational & N/A-occupational & Unknown & Unknown & 1918 [3] \\
\hline 36 workers & $\mathrm{N} / \mathrm{A}$ & Occupational & N/A-occupational & Unknown & $43^{\circ} \mathrm{C}\left(109.4^{\circ} \mathrm{F}\right)$ & $1919[6]$ \\
\hline M & & Weight loss & $2.5-5 \mathrm{~g}$ & $10 \mathrm{~h} 10 \mathrm{~min}$ & $>43^{\circ} \mathrm{C}\left(>110^{\circ} \mathrm{F}\right)$ & $1933[67]$ \\
\hline $\mathrm{F}$ & 46 & Weight loss & $300 \mathrm{mg}$ over 6 weeks & N/A & $40.4^{\circ} \mathrm{C}\left(104.8^{\circ} \mathrm{F}\right)$ & $1934[71]$ \\
\hline $\mathrm{F}$ & 31 & Weight loss & $6.06 \mathrm{~g}$ in 4 days & 16 days after start of trial & $38.9^{\circ} \mathrm{C}\left(102^{\circ} \mathrm{F}\right)$ & $1934[57]$ \\
\hline $\mathrm{F}$ & 25 & Weight loss & $2.88 \mathrm{~g}$ over 5 days & 7 days after first dose & $38.9^{\circ} \mathrm{C}\left(102^{\circ} \mathrm{F}\right)$ & $1934[46]$ \\
\hline $\mathrm{F}$ & NR & Weight loss & $\sim 10 \mathrm{~g}$ over 6 weeks & 5 days after admission & $41^{\circ} \mathrm{C}\left(105.8^{\circ} \mathrm{F}\right)$ & $1934[61]$ \\
\hline M & 37 & Weight loss & 9 g over 7 days & $11 \mathrm{~h}$ & $40.9^{\circ} \mathrm{C}\left(105.7^{\circ} \mathrm{F}\right)$ & $1934[51]$ \\
\hline $\mathrm{F}$ & 13 & Weight loss & $5.4 \mathrm{~g}$ over 46 days & $20 \mathrm{~h}$ after admission & $40.9^{\circ} \mathrm{C}\left(105.6^{\circ} \mathrm{F}\right)$ & $1936[47]$ \\
\hline $\mathrm{F}$ & 21 & Weight loss & $4.5 \mathrm{~g}$ & $9 \mathrm{~h} 10 \mathrm{~min}$ & $41.1^{\circ} \mathrm{C}\left(106^{\circ} \mathrm{F}\right)$ & $1936[56]$ \\
\hline M & NR & Overdose & Unknown & Approx. $12 \mathrm{~h}$ & Unknown & $1953[68]$ \\
\hline M & 61 & Accidental & Unknown & $24 \mathrm{~h}$ & Unknown & $1960[15]$ \\
\hline $\mathrm{F}$ & 17 & Weight loss & Unknown & $? 28 \mathrm{~h}$ & $38.5^{\circ} \mathrm{C}\left(101.4^{\circ} \mathrm{F}\right)$ & $2002[75]$ \\
\hline M & 22 & Weight loss & 2.4 g over 4 days & $17 \mathrm{~h}$ after last dose & $38.9^{\circ} \mathrm{C}\left(102^{\circ} \mathrm{F}\right)$ & $2004[28]$ \\
\hline $\mathrm{F}$ & 17 & Overdose & $2.3-2.88 \mathrm{~g}$ & $10 \mathrm{~h}$ & $>40^{\circ} \mathrm{C}\left(>104^{\circ} \mathrm{F}\right)$ & 2005 [69] \\
\hline M & 24 & Bodybuilding & Unknown & Unknown & $40.8^{\circ} \mathrm{C}\left(105.5^{\circ} \mathrm{F}\right)$ & 2005 [72] \\
\hline $\mathrm{F}$ & 17 & Bodybuilding & Unknown & $3 \mathrm{~h}$ after presentation & $39.4^{\circ} \mathrm{C}\left(103^{\circ} \mathrm{F}\right)$ & $2006[73]$ \\
\hline M & 28 & Bodybuilding & Unknown & 50 min after presentation & $41.1^{\circ} \mathrm{C}\left(106^{\circ} \mathrm{F}\right)$ & $2006[73]$ \\
\hline M & 30 & Bodybuilding & Unknown & Unknown & Unknown & $2007[74]$ \\
\hline $\mathrm{F}$ & 27 & Weight loss & Unknown over 1 week & $8 \mathrm{~h}$ after presentation & $38^{\circ} \mathrm{C}\left(100.4^{\circ} \mathrm{F}\right)$ & 2009 [21] \\
\hline M & 46 & Overdose & $2.8 \mathrm{~g}$ & $21 \mathrm{~h}$ & $37.8^{\circ} \mathrm{C}\left(100.0^{\circ} \mathrm{F}\right)$ & $2010[4]$ \\
\hline M & NR & Overdose & $2.8 \mathrm{~g}$ & $15 \mathrm{~h}$ & $39.5^{\circ} \mathrm{C}\left(103.1^{\circ} \mathrm{F}\right)$ & $2010[22]$ \\
\hline $\mathrm{F}$ & 49 & Occupational & N/A-cutaneous & $15 \mathrm{~h}$ & $38.9^{\circ} \mathrm{C}\left(102^{\circ} \mathrm{F}\right)$ & $2010[33]$ \\
\hline M & 41 & Occupational & N/A-cutaneous & $9 \mathrm{~h}$ & $38.5^{\circ} \mathrm{C}\left(101.3^{\circ} \mathrm{F}\right)$ & $2010[33]$ \\
\hline
\end{tabular}

$N R$ (not recorded)

last decade has seen the highest number of case reports from death due to intentional dinitrophenol overdose (Table 1).

\section{The Role of the Internet in Sourcing and Supplying Dinitrophenol}

Nowadays, DNP is sold mostly over the internet under a number of different names such as 'DNP', 'Dinosan', 'Dnoc', 'Solfo Black', 'Nitrophen', 'Aldifen' and 'Chemox'. The chemical is a yellow crystalline powder that has a sweet, musty odour and is soluble in water. The dose of DNP per capsule varies from website to website but it is most commonly sold as either 100- or 200-mg capsules. Some internet sites have DNP available in bulk quantities, allowing users to purchase kilograms of DNP powder or hundreds/ thousands of DNP-containing tablets, as well as offering free anabolic steroids and thyroxine to use in combination with the DNP $[5,19]$.

Websites often offer some advice for users around the use of DNP, although this is often targeted towards bodybuilders rather than for generic weight loss. A typical regimen would include starting with one capsule of DNP for the first few days followed by increasing doses to a recommended maximum of $400 \mathrm{mg} / \mathrm{day}$, which is then used for up to 2 weeks in duration $[5,19]$. These regimens may also include the use of anabolic steroids and/or thyroxine to increase muscle bulk. There is also the suggestion that 'crystalline' DNP is more potent than 'regular' DNP and therefore users should ensure they are aware of which type they are using and additionally, should limit the dose of crystalline DNP to no more than $200 \mathrm{mg} /$ day. These websites additionally describe the potential toxicity associated with the use of DNP including the potential for hyperthermia and death. Advice is provided to users on how to prevent hyperthermia developing, including use of air conditioning/fans and only exercising in cool areas whilst on the DNP phase of a 'treatment cycle' and carrying a thermometer to monitor body temperature [5]. They recommend that should body temperature rise above $38.9^{\circ} \mathrm{C}\left(102^{\circ} \mathrm{F}\right)$, the user should 'lower the DNP dose, take a very cold bath and ensure adequate hydration with water and juice-based drinks'. 
The marketed and desired beneficial effect of weight loss is reportedly not rapid enough for some individuals, and therefore they may take higher and potentially toxic doses in order to hasten the weight loss effects [20,21]. Additionally, there have been a number of recent fatalities due to intentional ingestion of DNP as suicide attempts [4, 22].

\section{Potential Mechanisms of Toxicity}

The classic symptom complex observed by overdose of phenol-based products such as DNP is a combination of hyperthermia, tachycardia, diaphoresis and tachypnoea $[4,21,22]$. There are thought to be several physiological mechanisms involved in the development of toxicity of DNP, which are summarised below.

\section{Uncoupling of Oxidative Phosphorylation}

DNP decreases the formation of high-energy phosphate bonds in mitochondria and at the same time stimulates systemic oxygen consumption [23]. This dissociative effect is known as uncoupling of oxidative phosphorylation. Adenosine triphosphate (ATP) production is the final product of the tricarboxylic acid (Krebs) cycle in mitocondria along with $\mathrm{CO}_{2}$ and $\mathrm{H}_{2} \mathrm{O}$. During glycolysis, there is a net production of two ATP molecules, but the majority of energy-rich phosphate bonds (38 in total) are produced during the final oxidative phosphorylation process. During this final phase, ATP synthetase converts adenosinediphosphate to ATP with the addition of an inorganic phosphate molecule. DNP interferes with the final energy production pathway by preventing the uptake of inorganic phosphate molecules into the mitochondria $[24,25]$. This results in the inhibition of all energy-requiring processes and the extra-mitochondrial accumulation of inorganic phosphate [26]. DNP also acts as a chemical ionophore, stopping the final energy conversion by exporting the proton ions $\left(\mathrm{H}^{+}\right)$needed for ATP production across the mitochondrial membrane by increasing the basal leak of protons [12]. This shift in the proton electrochemical gradient then results in potential energy dissipating as heat, instead of being converted to ATP, with rapid consumption of calories $[27,28]$. The heat production represents a failure in thermoregulatory homeostasis, leading to uncontrolled hyperthermia [29].

\section{Stimulation of Glycolysis}

El-Guindy et al. concluded that dinitrophenol produces its glycolytic effect through its effect on the muscle contraction process [30]. Carbohydrate consumption markedly increases in the presence of dinitrophenol which allows for rapid weight loss when dinitrophenol is taken in small doses [26]. Pyruvic acid is aerobically metabolised to $\mathrm{H}_{2} \mathrm{O}$ and $\mathrm{CO}_{2}$, but results in the production of lactic acid when metabolised anaerobically. The discrepancy between the stimulation of glycolysis and the inhibition of oxidative phosphorylation results in a rapid rise in the production of pyruvic acid, leading to an increased production of lactic acid $[24,26,31]$.

Potassium and Phosphate Accumulation

Mudge showed that potassium accumulates in rabbit kidney slices as the concentration of dinitrophenol is increased [32]. The accumulation of potassium continues even after cellular respiration is inhibited [32] and hyperkalaemia has contributed to toxicity [33]. Due to the uncoupling of oxidative phosphorylation, inorganic phosphate is no longer absorbed into the mitochondria and accumulation takes place, but whether this contributes to the clinical presentation is unknown [25, 34].

\section{Teratogenicity, Carcinogenicity and Other Toxicity}

In animal studies, DNP has been shown to be teratogenic, mutagenic and carcinogenic; developmental and reproductive toxicity has also been reported [35].

\section{Clinical Features of DNP Toxicity}

\section{Routes of Exposure}

The oral route is currently the most common route of therapeutic and suicidal exposure. Dermal exposure can cause yellow staining and may have mild corrosive effects on the skin. Absorption through the skin may lead to systemic effects similar to those seen following ingestion of DNP, although only mild symptoms are usually experienced. Exposure to the eyes may cause yellow discoloration of the sclera with conjunctival injection and irritation. Dermal exposure is the most common route of unintentional exposure [6, 33]. DNP is used in the chemical industry in wood preservatives, herbicides and dyes and may leak onto industrial sites through landfill and storage tanks. Accidental spills during manufacture and transport are possible and exposure is usually through exposure to the water or dirt that it has leaked on. Although there have been no reports of this occurring, there have been two fatalities related to individuals recycling nylon bags that had previously contained DNP [33]. Inhalational exposure can happen by breathing contaminated air at DNP-containing waste sites or from incineration fumes. Inhalation of DNP fumes may lead to significant systemic effects, similar to those seen with ingestion. 
Organ Systems Affected by Therapeutic Use

There is a small margin between the beneficial effects and the toxic effects of DNP. The most common side effect reported with the therapeutic use of DNP is a rash $[6,36-$ 38]. This rash can be maculo-papular, urticarial, angiooedematous or a severe exfoliative dermatitis [39-41]. There is often accompanying pruritis and subsequent desquamation [39, 41, 42]. Prolonged peripheral neuritis has been reported, often affecting the hands and feet and associated with skin changes [11, 43, 44]. A common complaint is that of yellow discoloration of the skin, sclera and urine [45-48]. This same yellow discoloration is often seen at autopsy and has been confused with jaundice due to reports of liver damage [36, 45, 49-52].

T wave and ST segment abnormalities have been noted and some of the earlier autopsied case reports recorded heart muscle damage [46, 50, 53]. Gastroenteritis and anorexia have been reported in high doses [11, 36]. Acute kidney injury, as evidenced by acute tubular necrosis, has been found at autopsy and also reported in two other cases $[46,54,55]$. Confusion, agitation, convulsion and coma are the most common neurological effects reported [50, 56, 57].

Agranulocytosis and neutropaenia have been associated with the therapeutic use of DNP [36, 37, 45, 47, 58-61]. Cataracts can develop quickly after the use of DNP, usually leading to a permanent decrease in vision to light-dark perception in days to months [62-65]. Permanent deafness has been reported at doses considered to be therapeutic [66].

\section{Intentional Overdose}

The average time to presentation in the reported cases of acute or suicidal overdose is $7-8 \mathrm{~h}$ and the average time of death is $14 \mathrm{~h}[4,15,22,51,56,67-69]$. The onset of symptoms was reported as early as $3 \mathrm{~h}$ and $30 \mathrm{~min}$ after the overdose [56]. The usual complaint of the patient is that of profuse sweating [46]. The initial fever is not associated with a change in heart rate or blood pressure, but tachycardia, tachypnoea, shock, confusion, convulsions, cardiovascular collapse and pulseless electrical activity are the eventual consequence of the fatal, deliberate overdose, regardless of treatment $[4,15,22$, $51,56,67-69]$. However, there has been at least one case of survival following deliberate overdose in an 18-year-old female who developed typical features of DNP toxicity [tachycardia of 144 beats per minute, tachypnoea of 38-40 breaths per minute and hyperthermia of $\left.39.7^{\circ} \mathrm{C}\left(103.4^{\circ} \mathrm{F}\right)\right]$ [70]. She was managed conservatively with intravenous fluids and ice packs to maintain her temperature below $38.3^{\circ}$ $\mathrm{C}\left(101^{\circ} \mathrm{F}\right)$ and was discharged less than $48 \mathrm{~h}$ following admission to hospital with no adverse effects at the time of discharge. Ingestion of DNP was confirmed by analysis of gastric lavage contents.

\section{DNP-Related Fatalities}

Fatalities from the intake of DNP, whether accidental or suicidal, have been reported since the turn of the twentieth century (Table 1). To date, there have been 62 published deaths attributed to DNP (Fig. 1). The largest publication of 36 deaths due to DNP was published in 1919 [6]. This was a study into the deaths in munition factories in Paris due to occupational exposure to DNP. It highlights the improvements made in the factory to prevent further deaths through simple measures such as ventilation, personal protective equipment and better hygiene. This combined with changes in legislation brought the death rate down from 16.3 per $10,000 \mathrm{t}$ of DNP handled/produced to 1.2 per $10,000 \mathrm{t}$.

During the 1930s, reported DNP-related fatalities were all individuals who had taken it for weight loss [46, 47, 51, $56,57,61,67,71]$. After the 1930s, there have only been two fatalities in the remainder of the twentieth century $[15,68]$. One related to deliberate ingestion of DNP [68] and the other was where an individual accidentally ingested a liquid he thought to be grape juice, but in fact contained derivatives of DNP [15]. This further decline in fatalities may reflect the labelling of DNP as 'extremely dangerous and not fit for human consumption' by the US Food and Drug Administration in 1938.

Over the last decade, from 2001 to 2010, there have been 12 deaths related to exposure to DNP. These fatalities have been linked to deliberate overdose $[4,22$, 69], accidental toxicity associated with use by bodybuilders or for weight loss [21, 28, 72-75] and accidental occupational exposure [33]. This resurgence in reported fatalities may reflect the increased availability of DNP over the internet, marketed particularly towards bodybuilders.

Preceding death, the patient is often profoundly hyperthermic and there may be associated methaemoglobinaemia. Death is usually secondary to massive cardiovascular collapse. There have been frequent reports of a rapid (within minutes) onset of generalised rigidity after death $[6,11]$. This profound muscle rigidity has also been seen to happen before death making mechanical ventilation very difficult [21]. This early onset of generalised rigidity after death has been attributed to the release of calcium from the cytosol due to the depletion of ATP [22].

Ingestion is currently the most common route of exposure to the drug leading to death. The lowest published lethal human oral dose of DNP is $4.3 \mathrm{mg} / \mathrm{kg}$ [76]; the doses reported in the published acute and suicidal fatalities range from $2.8 \mathrm{~g}$ to an estimated $5 \mathrm{~g}$. The highest reported dose taken in acute overdose associated with survival was a woman who took $2.4 \mathrm{~g}$ with no complications [70]. 


\section{Options for Management}

There is no specific antidote for DNP poisoning and all management strategies are based on case reports and expert opinions, but the key to the management of DNP poisoning lies in early recognition and a high index of suspicion [46]. Patients who have acutely overdosed on DNP in any form should be observed for at least $12 \mathrm{~h}$, as no patient has been recorded to be asymptomatic beyond $10 \mathrm{~h}$ after an acute overdose [4]. During this time, their body temperature, cardiac rhythm, heart rate and oxygen saturation should be carefully monitored.

Although there are no previous reports of its use, in line with the previously published American Academy of Clinical Toxicology/European Association of Poisons Centres and Clinical Toxciologists position statements on the use of oral activated charcoal, we would recommend consideration of a single dose of activated charcoal in those individuals who present within an hour of ingestion. Previous autopsies have reported a yellow coloured fluid in the intestines of some cases; there is no evidence that this fluid contains DNP rather than staining following ingestion. Therefore, at this time although there is no evidence to support the use of multi-dose activated charcoal and/or whole bowel irrigation, we feel that the potential benefit outweighs the potential risk. External decontamination, if appropriate, should be undertaken by washing to reduce dermal exposure. Based on the underlying pathophysiological principles and previous experience, it would be advisable to avoid the use of salicylates as it may worsen the DNP-related toxidrome [77, 78]. Aggressive fluid resuscitation should be initiated, using cooled fluids in those with hyperthermia.

Seizures should be controlled with benzodiazepines. These may also be needed to control severely agitated patients, as their agitation will add to the hyperthermic state which may lead to circulatory collapse. External cooling measures with ice or cooling blankets should be initiated to control hyperpyrexia [11, 70, 79-81]. If benzodiazepines do not control agitation or seizures, then paralysis, intubation and ventilation should be considered. Dantrolene and ice baths have been used to control the severe hyperthermic state $[46,82]$. There is the possibility for the use of external cooling devices, such as those used to induce therapeutic hypothermia following an out of hospital cardiac arrest, to rapidly reduce temperature; however, there have been no previous reports of using these devices in patients with DNP toxicity. Dantrolene has previously been recommended to manage the hyperthermia associated with the use of DNP. There is no evidence to support this recommendation, but it has been used successfully in a single case report [34, 82].

Intravenous vasopressors and/or inotropes should be considered accompanied with invasive arterial monitoring if fluid therapy fails to maintain the blood pressure. Cardiopul- monary resuscitation was performed in some of the cases of DNP overdose and in one case for up to an hour [69], but has never led to a return of spontaneous circulation. Halothane should be avoided as possible synergistic hyperthermia may cause deterioration and death [29].

Methaemoglobinaemia should always be suspected and tested for. Levels exceeding $30 \%$ should be treated with intravenous methylthioninium chloride (methylene blue), but treatment may be started at lower serum methaemoglobin levels in the presence of other signs of shock and tissue hypoperfusion.

The use of continuous veno-venous haemofiltration $(\mathrm{CVVH})$ has been recommended to manage hyperkalaemia and hyperthermia associated with DNP overdose [4, 83]. However, there are no published cases in which CVVH or similar therapies have been used in DNP poisoning.

Propranolol has been studied in dogs poisoned by DNP and a significant reduction in lactate levels was recorded [25], but its clinical use in humans cannot be recommended due to the inhibitory effect on glucose production and unknown effect on mortality. High-dose insulin and glucose may have a beneficial effect through facilitation of glycolysis, but there is no animal or human data to support this treatment modality at this time [84]. However, glucose administration alone may be useful since glycolysis would be the main source of ATP production in DNP-poisoned cells [85].

\section{Summary}

DNP has been available for over a century, initially in the manufacture of munitions, due to its explosive properties. From the 1930s onwards, there has been interest in its properties to increase the underlying metabolic rate, leading to an associated weight loss. Following a number of deaths in the 1930s, the US Food and Drug Administration determined that DNP was 'extremely dangerous and not fit for human consumption'. There were very few reported deaths since the late 1930s, until the last decade. It appears that there has been increasing interest and availability of DNP-containing products on the internet. Whilst these appear to be largely targeted towards bodybuilders to try and reduce fat and improve muscle bulk, there have been a number of deaths related to its use for more general weight loss. The primary toxicity seen with DNP is similar to that seen with other phenol-based products and is a combination of hyperthermia, tachycardia, diaphoresis and tachypnoea with associated cardiovascular collapse/cardiac arrest and death. There is no specific management for individuals with DNP-related toxicity; it is imperative that the temperature is brought down as rapidly and as soon as possible to try and reduce systemic toxicity and/or death. Currently, DNP remains freely available on the internet, with both detailed 
'regimens' for its use and about the potential for acute toxicity and death on the internet seller websites. It is likely that some individuals, despite these warnings, will continue to purchase and use DNP-containing products to aid with weight loss, with the potential risk of acute toxicity and/or death.

\section{Conflict of Interest None}

\section{References}

1. Logue J, Thompson L, Romanes F, Wilson DC, Thompson J, Sattar N (2010) Management of obesity: summary of SIGN guideline. BMJ 340:c154

2. Colman E (2007) Dinitrophenol and obesity: an early twentiethcentury regulatory dilemma. Regul Toxicol Pharmacol 48:115117

3. Warthin AS (1918) A fatal case of toxic jaundice caused by dinitrophenol. Bull Int Assoc Med Mus 7:123-126

4. Bartlett J, Brunner M, Gough K (2010) Deliberate poisoning with dinitrophenol (DNP): an unlicensed weight loss pill. Emerg Med J 27:159-160

5. BuyDinitrophenol.com (2011). Available from: http://www. buydinitrophenol.com/. Accessed 27 May 2011

6. Perkins RG (1919) A study of munitions intoxications in France. Pub Health Rep 34:2335

7. Cutting WC, Mehrtens HG, Tainter ML (1933) Actions and uses of dinitrophenol. JAMA 101:193-195

8. Tainter ML, Stockton AB, Cutting WC (1933) Use of dinitrophenol in obesity and related conditions. A progress report. JAMA 101:1472-1475

9. Tainter ML, Cutting WC, Hines E (1935) Effects of moderate doses of dinitrophenol on the energy exchange and nitrogen metabolism of patients under conditions of restricted dietary. $\mathrm{J}$ Pharmacol Exp Ther 55:326-353

10. Dunlop DM (1934) The use of 2:4-dinitrophenol as a metabolic stimulant. BMJ 3820:524

11. Tainter ML (1935) Treatment of acute dinitrophenol poisoning. JAMA 104:1071-1072

12. Harper JA, Dickinson K, Brand MD (2001) Mitochondrial uncoupling as a target for drug development for the treatment of obesity. Obes Rev 2:255-265

13. Agency for Toxic Substances \& Disease Registry (1995) Toxicological profile of dinitrophenols. Available from: http://www.atsdr.cdc. gov/toxprofiles/tp.asp?id=729\&tid=132. Accessed 27 May 2011

14. Gisclard JB, Woodward MM (1946) 2,4-Dinitrophenol poisoning; a case report. J Ind Hyg Toxicol 28:47-51

15. Cann HM, Verhulst HL (1960) Fatality from acute dinitrophenol derivate poisoning. Am J Dis Child 100:947-948

16. Kurt TL, Anderson R, Petty C et al (1986) Dinitrophenol in weight loss: the poison centre and public safety. Vet Hum Toxicol 28:574-575

17. Miami FBI (2008) Helvetia defendant sentenced to 14 years on wire and securities fraud. Available from: http://miami.fbi. gov/dojpressrel/pressrel08/mm20081203.htm. Accessed 27 May 2011

18. Food Standard Agency (2011) Food Standards Agency issues urgent advice on consumption of 'fat burner' capsules containing DNP. Available from: http://www.food.gov.uk/news/pressreleases/ 2003/jun/fatburnpress. Accessed 27 May 2011

19. Welcome to BuyBestAnabolicSteroids.com (2011) Available from: http://www.buybestanabolicsteroids.com/. Accessed 27 May 2011
20. Author unknown. Death after slimming treatment. The Lancet 1934;3:489

21. Tewari A, Ali A, O'Donnell A, Butt MS (2009) Weight loss and 2,4-dinitrophenol poisoning. Br J Anaesth 102:566-567

22. Siegmueller C, Narasimhaiah R (2010) Fatal 2,4-dinitrophenol poisoning... coming to a hospital near you. Emerg Med J 27:639640

23. Author unknown. Dinitrophenol and accelerated tissue metabolism. JAMA 1933;101:2122-2123

24. Rognstad R, Katz J (1969) The effect of 2,4 dinitrophenol on adipose-tissue metabolism. Biochem J 111:431-444

25. Issekatz B (1984) Effect of propranolol in dinitrophenol poisoning. Arch Int Pharmacodyn 272:310-319

26. Simon EW (1953) Mechanisms of dinitrophenol toxicity. Biological rev 28:453-478

27. Wallace KB, Starkov AA (2000) Mitochondrial targets of drug toxicity. Annu Rev Pharmacol Toxicol 40:353-388

28. McFee RB, Caraccio TR, McGuigan MA, Reynolds SA, Bellanger P (2004) Dying to be thin: a dinitrophenol related fatality. Vet Human Toxicol 46:251-254

29. Hoch FL, Hogan FP (1973) Hyperthermia, muscle rigidity, and uncoupling in skeletal muscle mitochondria in rats treated with halothane and 2,4 dinitrophenol. Anaesthesiology 38:237-243

30. El-Guindy MM, Neder AC, Gomes CB (1981) 2,4-Dinitrophenol - mechanism of action. Cell Mol Biol 27(5):399-402

31. Krahl ME, Clowes GHA (1935) Some effects of dinitrocresol on oxidation and fermentation. J Biol Chem 111:355

32. Mudge GH (1951) Electrolyte and water metabolism of rabbit kidney slices: effect of metabolic inhibitors. Amer J Physiol 167:206

33. Jiukun J, Zhihua Y, Weidong H, Jiezan W. (2011) 2,4 Dinitrophenol poisoning caused by non-oral exposure. Toxicol Ind Health. doi:0748233710387004

34. Moffatt EJ, Miyamoto MD (1988) Effect of sodium and calcium channel blockade on the increase in spontaneous transmitter release produced by the mitochondrial inhibitor, dinitrophenol. J Pharmacol Exp Ther 244:613-618

35. Takahashi M, Sunaga M, Hirati-Koizumi M, Hirose A, Ema M (2009) Reproductive and developmental toxicity screening study of 2,4-dinitrophenol in rats. Environ Toxicol 24:74-81

36. Tainter ML, Cutting WC, Stockton AB (1934) Use of dinitrophenol in nutritional disorders. Am J Public Health Nations Health 24:10451053

37. Tainter ML, Cutting WC (1933) Febrile, respiratory and some other actions of dinitrophenol. J Pharmac Exp Ther 105:332337

38. Anderson HH, Reed AC, Emerson GA (1933) Toxicity of alphadinitrophenol. Report of a case. JAMA 101:1053-1055

39. Jackson H, Duvall AI (1934) Dinitrophenol poisoning: report of a case. JAMA 102:1844-1845

40. Hitch JM, Schwartz WF (1936) Late toxic results, including dermatitis exfoliativa, from "slim" (Dinitrophenol). JAMA 106:2130-2132

41. Frumess GM (1934) Allergic reaction to dinitrophenol. Report of a Case. JAMA 102:1219

42. Hirsch S (1934) Report of a toxic manifestation of "Dinitrenal". JAMA 102:950

43. Nadler JE (1935) Peripheral neuritis caused by prolonged use of dinitrophenol. JAMA 1:12-13

44. Tainter ML, Stockton AB, Cutting WC (1935) Dinitrophenol in the treatment of obesity. JAMA 105:332-337

45. Davidson EN, Shapiro M (1934) Neutropenia following dinitrophenol, with improvement after pentnucleotide and leukocyte cream. JAMA 103:480-482

46. Poole FE, Haining RB (1934) Sudden death from dinitrophenol poisoning. JAMA 102:1141-1147 
47. Goldman A, Haber M (1936) Acute complete granulopenia with death due to dinitrophenol poisoning. JAMA 107:2115-2117

48. Haft HH (1933) Toxicity of dinitrophenol. JAMA 101:1171

49. Isaacs BL (1934) "Dinitrophenol poisoning". JAMA 102:2218

50. Tainter ML, Wood DA (1934) A case of fatal dinitrophenol poisoning. JAMA 102:1147-1149

51. Tainter ML (1934) Low oxygen tensions and temperatures on the actions and toxicity of dinitrophenol. J Pharmacol Exper Therap $51: 45-58$

52. Sidel N (1934) Dinitrophenol poisoning causing jaundice. JAMA 103:254

53. MacBryde CM, Taussig BL (1935) Functional changes in liver, heart and muscles, and loss of dextrose tolerance resulting from dinitrophenol. JAMA 105:13-17

54. Rabinowitch IM, Fowler AF (1934) Dinitrophenol. Canad M A J 30:128

55. De Chatel A, Motika J (1934) Ueber die gefahren der therapeutischen anwendung des alpha-dinitrophenols. Deutsch Arch f Klin Med 176:700

56. Purvine R (1936) Fatal poisoning from sodium dinitrophenol. JAMA 107:2046

57. Masserman JH, Goldsmith H (1934) Dinitrophenol: its therapeutic and toxic actions in certain types of psychobiologic underactivity. JAMA 102:523

58. Hoffman AM, Butt EM, Hickey NG (1934) Neutropenia following amidopyrine: preliminary report. JAMA 102:1213

59. Imerman SW, Imerman CP (1936) Dinitrophenol poisoning. JAMA 106:1085-1087

60. Bohn SS (1934) Agranulocytic angina following ingestion of dinitrophenol. JAMA 103:249-251

61. Silver S (1934) A new danger in dinitrophenol therapy. Agranulocytosis with fatal outcome. JAMA 103:1058

62. Boardman WW (1935) Rapidly developing cataract after dinitrophenol. JAMA 105:108

63. Lazar NK (1935) Cataract following the use of dinitrophenol. JAMA 105:794

64. Kniskern PW (1935) Cataracts following dinitrophenol. JAMA 105:794-795

65. Allen TD, Benson VM (1935) Late development of cataract following use of dinitrophenol about a year before. JAMA 105:795

66. Dintenfass H (1934) An ear complication from dinitrophenol medication. JAMA 102:838

67. Gieger JC (1933) A death from alpha-dinitrophenol poisoning. JAMA 101:1333

68. Swamy SA (1953) Suicidal poisoning by dinitrophenol. J Indian Med Assoc 22:504-5

69. Hsiao AL, Santucci KA, Seo-Mayer P, Mariappan MR, Hodsdon ME, Banasiak KJ, Baum R (2005) Pediatric fatality following ingestion of dinitrophenol: postmortem identification of a "dietary supplement". Clin Toxicol 43:281-285
70. Geiger JC (1935) Case of dinitrophenol poisoning with recovery. JAMA 104:915

71. Dameshek W, Gargill SL (1934) Report of two cases of agranulocytosis following the use of dinitrophenol. New England J Med 211:440

72. Suozzi JC, Rancont CM, McFee RB (2005) DNP 2,4-dinitrophenol: a deadly way to lose weight. JEMS 30:82-89

73. Miranda EJ, McIntyre IM, Parker DR, Gary RD, Logan BK (2006) Two deaths attributed to the use of 2,4-dinitrophenol. J Anal Toxicol 30:219-222

74. Politi L, Vignali C, Polettini A (2007) LC-MS-MS analysis of 2, 4-dinitrophenol and its phase I and II metabolites in a case of fatal poisoning. J Anal Toxicol 31:55-61

75. Pace SA, Pace S (2002) Dinitrophenol oral ingestion resulting in death. J Toxicol Clin Toxicol 40:683

76. The physical and theoretical Chemistry Laboratory Oxford University (2011) Material safety data sheet for 2,4-dinitrophenol. Available from: http://msds.chem.ox.ac.uk/DI/2,4-dinitrophenol. html Accessed 27 May 2011

77. Leftwich RB, Floro JF, Neal RA, Wood AJJ (1982) Dinitrophenol poisoning: a diagnosis to consider in undiagnosed fever. South Med J 75:182-189

78. Gabbay KH (1972) Role of sorbitol pathway in neuropathy. In: Camerini-Davalos RA, Cole HS (eds) Vascular and neurological changes in early diabetes. Academic Press, New York, pp 417424

79. Bronstein AC, Currance PL (1988) Emergency care for hazardous material exposure. Mosby, St Louis, pp 159-160

80. Ellenhorn MJ, Barceloux DG (1988) Medical toxicology: diagnosis and treatment of human poisoning. Elsevier, Amsterdam, pp 1096-1097

81. Haddad LM, Winchester JF (1990) Clinical management of poisoning and drug overdose, 2nd edn. Saunders, Philadelphia, pp 1079-1081

82. Kumar S, Barker K, Seger D (2002) Dinitrophenol-induced hyperthermia resolving with dantrolene administration. Clin Toxicol 40:599-673

83. House A, Ronco C (2008) Extracorporeal blood purification in sepsis and sepsis-related acute kidney injury. Blood Purif 26:30 35

84. Nakamura S, Kiyosue T, Arita M (1989) Glucose reverses 2, 4-dinitrophenol induced changes in action potentials and membrane currents of guinea pig ventricular cells via enhanced glycolysis. Cardiovasc Res 23:286-294

85. Agency for Toxic Substances and Disease Registry (1995) Toxicological profile for dinitrophenols. Available from: http:// www.atsdr.cdc.gov/toxprofiles/tp.asp?id=729\&tid=132. Accessed 27 May 2011

86. Barral MB (1916) Intoxication par le dinitrophenol. Lyon Med $125: 276$ 